\title{
Effect of Laparoscopic Adhesiolysis of Pelvic Adhesions in Management of Chronic Pelvic Pain on Quality of Life
}

\author{
Original Hossam Abdel Mageed Abdou', Mohamed Eid Ismail', Haitham Osama \\ Article \\ Elboraie $^{3}$, Yasser Abou Talib ${ }^{4}$ \\ ${ }^{1,2}$ Department of Obstetrics and Gynecology, ${ }^{3}$ Department of Psychiatry, Faculty of Medicine, \\ Helwan University, ${ }^{4}$ Department of Obstetrics and Gynecology, Ain-Shams University, \\ Cairo , Egypt
}

\begin{abstract}
Background: Chronic pelvic pain has been described in a variety of ways, it is most commonly defined as non-menstrual pelvic pain of 6 months or more duration, that is severe enough to cause functional disability or require medical or surgical treatment. Adhesions are diagnosed in approximately $25 \%$ of women with chronic pelvic pain.

Aim: The aim of the present study was to compare between quality of life before and after laparoscopic adhesiolysis in the management of chronic pelvic pain.

Materials and Methods: This study was prospective cohort study which included 20 patients and carried out at Helwan University Hospitals between December 2018 and December 2019 over 12 months. All of the patients completed general health questionnaire (GHQ) preoperatively. All laparoscopies were done by the same operator. Complete adequate laparoscopic adheseolysis was the aim of laparoscopy. All patients completed the questionnaire again 2 weeks and 3 months postoperatively.

Results: Fifteen patients improved after 2 weeks and 18 patients after 3 months 2 patients has no improvement and quality of life for these patients has significant improvement after laparoscopic adhesiolysis.

Conclusion: Laparoscopic adhesiolysis seems to be effective regarding improvement of quality of life in patient with chronic pelvic pain.
\end{abstract}

Key Words: Adhesions, adhesiolysis, chronic pelvic pain, laparoscopy

Received: 11 March 2020, Accepted: 11 March 2020

Corresponding Author: Hossam Abdou, Department of Obstetrics and Gynecology, Faculty of Medicine, Helwan University, Egypt, Tel.: +201205792339, E-mail: hossam_mansy80@yahoo.com

ISSN: 2090-7265, August 2020, Vol.10, No. 3

\section{INTRODUCTION}

Although chronic pelvic pain has been described in a variety of ways, it is most commonly defined as nonmenstrual pelvic pain, of 6 months or more duration, that is severe enough to cause functional disability or require medical or surgical treatment ${ }^{[1]}$.

Chronic pelvic pain is a debilitating condition among women with a major impact on health-related quality of life, on work productivity, and on the health care system and concerns about $4 \%$ of women ${ }^{[2]}$.

The etiology of chronic pelvic pain may be characterized as visceral or somatic visceral disorders can arise in genitourinary or gastrointestinal organs (e.g. endometriosis, adhesions, ovarian masses, pelvic inflammatory disease, malignancies, constipation, or irritable bowel syndrome $)^{[3]}$.
Laparoscopy is considered gold standard for the evaluation and treatment of pelvic pain. However, this procedure should be undertaken only after a complete multidiscipline diagnostic evaluation has been carried out and a potential diagnosis has been reached but many causes of CPP (chronic pelvic pain) cannot be detected at laparoscopy ${ }^{[4]}$.

Adhesions may be a physical cause for abdominal or pelvic pain, and are known to develop after more than $90 \%$ of abdominal surgeries ${ }^{[5]}$. Adhesiolysis may be beneficial for patients with chronic pelvic pain especially those who have undergone laparotomy, or if there was suspected intestinal involvement ${ }^{[6]}$.

\section{AIM OF THE WORK}

The aim of this study was to compare between quality of life before and after laparoscopic adhesiolysis in the management of chronic pelvic pain. 


\section{PATIENTS AND METHODS}

This was a prospective cohort study which included twenty patients who were diagnosed with chronic pelvic pain in outpatient clinic at Helwan University Hospitals between December 2018 and December 2019 over 12 months to compare between quality of life before and after laparoscopic adhesiolysis in the management of chronic pelvic pain.

All women with chronic pelvic pain included in the study should fulfill the following criteria: pelvic pain more than 6 months, conditions with etiological factors of pelvic pain due to inflammatory or past pelvic surgical causes, benign conditions, age between 20-50 years and BMI from 19-40.

Exclusion criteria were acute pelvic pain or chronic pelvic pain less than 6 months, age below 20 or above 50 years, BMI above 40, pure dyspareunia or dysmenorrhea, malignancy (cancer cervix or cancer endometrium) and incomplete laparoscopic adheseolysis.

Detailed evaluation of the patient preoperatively included full history taking, general examination, abdominal and local examination and any needed investigations including radiology. The 20 patients were divided into two groups : group (A) has no previous abdominal surgery (5 patients) and group (B) has previous abdominal surgery (15 patients) adequate counselling and informed consent from the patient about the suggested management laparoscopic adheseolysis.

Preoperatively, all the patients completed general health questionnaire (GHQ) 28. It was chosen as it is valid, responsive, reproducible and reliable. It was done by Goldberg (1978) and translated into Arabic by Abdelaziz Mosa Thabet professor of Psychiatry Al-Quds University. The (GHQ) 28 questions were presented to the patient with 4 possible answers : the score of the first two answers is 0 and the score of the last two answers is 1 . So, the least score is zero (perfect quality of life) and the maximum score is 28 (maximum affection of the quality of life) (Appendix 1).

All laparoscopies done by the same operator H.A. Complete adequate laparoscopic adheseolysis was the aim of laparoscopy ZERO ADHESIONS. Patient's follow-up appointment was scheduled. Follow up of all included patients postoperatively and completed (GHQ) questionnaire 2 weeks and 3 months after operation.

\section{RESULTS}

The experimental data were collected spastically analyzed according to factorial experiment in a completely prospective cohort study design to study the effect of the individual factors as well as the interactions. Data were computed in order to ascertain that the observed effects were real and discernable from chance effect. Statistical analysis was carried out using Statistical packagel for windows program. Descriptive data was summarized as means and standard deviations $( \pm \mathrm{SD})$, differences were considered significant when $P$ value $\leq 0.05$ and were considered non-significant when $P$ value $\geq 0.05$. Age was not statistically significant between patients of the study p-value 0.261 (Table 1).

The mean General Health Questionnaire (GHQ) score for group A preoperative was 19.2 and improved 2 weeks postoperatively to be 11.4 . The mean General Health Questionnaire (GHQ) score for group B was preoperative 20.4 and improved 2 weeks postoperatively to be 15.4 . There were significant statistical differences between preoperative and postoperative quality of life; $p$-value 0.02 and 0.04 , respectively (Table 2 ).

The mean General Health Questionnaire (GHQ) score for group A preoperative was 19.2 and improved 3 months postoperatively to be 5 . The mean General Health Questionnaire (GHQ) score for group B preoperative was 20.4 and improved 3 months postoperatively to be 11.47. There were significant statistical differences between preoperative and post-operative quality of life; $p$-value 0.003 and 0.002 , respectively (Table 3 ).

Postoperative evaluation of pain after adhesiolysis, the number of successes patients after 2 weeks 15 patient and 18 after three months, however the number of failed patients after two weeks was five and two after three months (Table 4). 
Table 1: The mean and SD for age

\begin{tabular}{cccc}
\hline & Age & S-value \\
\hline Mean & SD & 0.261 \\
31.3 & 6.41 & 0.21 \\
\hline
\end{tabular}

Table 2: GHQ score after 2 weeks for groups A and B

GHQ Score for group (A) after 2 weeks

\begin{tabular}{cc} 
Preoperative $(\mathrm{N}=5)$ & Post-operative $(\mathrm{N}=5)$ \\
$19.2 \pm 3.77$ & $11.4 \pm 2.56$ \\
& GHQ Score for group $(\mathrm{B})$ after 2 weeks \\
Preoperative $(\mathrm{N}=15)$ & Post-operative $(\mathrm{N}=15)$ \\
$20.4 \pm 3.94$ & $15.4 \pm 2.85$ \\
\hline
\end{tabular}

Table 3: GHQ score after 3 months for groups A and B

GHQ Score for group (A) after 3 months

$\begin{array}{ccc}\text { Preoperative }(\mathrm{N}=5) & \text { Post-operative }(\mathrm{N}=5) & P \text {-value } \\ 19.2 \pm 3.77 & 5 \pm 2.1 & 0.003\end{array}$

GHQ Score for group (B) after 3 months

Preoperative $(\mathrm{N}=15)$

Post-operative $(\mathrm{N}=15)$

$P$-value

$20.4 \pm 3.94$

$11.47 \pm 2.73$

0.002

Table 4: Summary of post-operative evaluation of pain after adhesiolysis

\begin{tabular}{lcc}
\hline Summary & After 2 weeks & After 3 months \\
\hline Number of improved patient & 15 & 18 \\
Number of failed patient & 5 & 2 \\
\hline
\end{tabular}




\section{DISCUSSION}

Pelvic adhesions can be caused by surgery or by a variety of diseases including endometriosis, pelvic inflammatory disease, and appendicitis. In general, any pelvic inflammatory process can cause adhesion formation, which in turn can lead to infertility, bowel obstruction, and chronic pain ${ }^{[7]}$.

The incidence of pelvic adhesions in the general population is not known; however, earlier publications report that $27 \%$ to $60 \%$ of patients undergoing laparoscopy for pelvic pain are found to have adhesions at the time of laparoscopy ${ }^{[8]}$.

The role of adhesions in the development of chronic pelvic pain remains controversial. Most women with pelvic adhesions are asymptomatic. In cases where pain and adhesions are present, the extent or location of adhesive disease does not always correlate with intensity of pain ${ }^{[9]}$. Moreover, there are no findings that can reliably predict the presence or absence of adhesions. Previous pelvic or abdominal surgery seems to be the only historical predictor associated with adhesive disease ${ }^{[10]}$.

Laparoscopy for removal of adhesions is superior than laparotomy because of the faster recovery and the diminished overall tissue trauma, which may increase the risk of reformation of adhesions ${ }^{[11]}$.

In this study, the 20 patients were divided into two groups; group A included 5 patients with no previous abdominal surgery and group B included 15 patients with previous abdominal surgery. The study found significant statistical differences between preoperative and postoperative quality of life score for group A after two weeks ( $p$-value 0.02) and after 3 months ( $p$-value 0.003), respectively. Also, the study found significant statistical differences between preoperative and postoperative quality of life score for group B after two weeks ( $p$-value 0.04) and after 3 months ( $p$-value 0.002), respectively. The study revealed that 15 patents improved after 2 weeks and 18 patients after 3 months; 2 patients showed no improvement. The score for the improved patients improved from 2 weeks to 3 months.

These results seem logic confirming the role of laparoscopic adheseolysis in improving quality of life in cases of chronic pelvic pain with a ratio of $10 \%$ not improved may be due to presence of other factors.

The results of our study goes with ${ }^{[1]}$ that had retrospective data from when the clinic was founded in 2003; her initial surgery was in 2003 with a reoccurrence of symptoms after being pain free for 13 years in their study follows a patient's self-reported pain and it showed an interval improvement of pain for an extended period of time. For women who underwent initial adhesiolysis and for those who have had consecutive lysis of adhesions continued to show an improvement of pelvic pain for a significant period of time.

The results of our study goes with a review of several observational studies that found improvement in symptoms following adhesiolysis between 38\% and $84 \%$, but these findings has low variability in follow-up time and loss of consistency by using of standardized pain assessment tools ${ }^{[13]}$.

Laparoscopy is the preferred surgical method; however, these surgeries are often difficult, because of dense adhesions, and require extensive laparoscopic experience. Current published reports demonstrate marginal pain relief after surgery with one study showing that only $48 \%$ of women experienced prolonged relief after laparoscopic treatment of ovarian retention syndrome ${ }^{[14]}$.

The benefit of adhesiolysis has been cast into serious doubt by a recent well-designed randomized controlled trial of laparoscopic adhesiolysis versus diagnostic laparoscopy in a cohort of men and women. This trial of 100 participants with chronic abdominal pain showed no difference in outcomes between the two groups on verbal rating pain change scale, visual analogue scale, and quality of life instruments. At 1-year follow-up, $27 \%$ reported having relief or much improved pain in both groups ${ }^{[15]}$.

There is a need for a larger study including more patients. Also, more follow up will be recommended to detect the long term effect of laparoscopic adheseolysis.

\section{CONCLUSION}

Laparoscopic adhesiolysis seems to be effective regarding improvement of quality of life in patient with chronic pelvic pain.

\section{CONFLICT OF INTEREST}

There are no conflicts of interests.

\section{REFERENCES}

1. Steege JF and Siedhoff MT. (2014). chronic pelvic pain. Obstet Gynecol 124:616-629.

2. Howard FM. (2003). Chronic pelvic pain. Obstet Gynecol; 101:594.. 
3. Vercellini $\mathrm{P}$, Somigliana $\mathrm{E}$, Vigano $\mathrm{P}$, et al. (2009). Chronic pelvic pain in women: etiology, pathogenesis and diagnostic approach. Gynecol Endocrinol 25:149-158.

4. Olive DL, Parker WH, Cooper JM, et al. (2000): The AAGL classification system for laparoscopic hysterectomy: From the classification committee of the American Association of Gynecologic Laparoscopists. The Journal of the American Association of Gynecologic Laparoscopists; 7(1):9-15.

5. Yosef A, Ahmed AG, Al Hussaini T, et al. (2016). Chronic pelvic pain: Pathogenesis and validated assessment. Middle East Fertil Soc J 21(4): 205-221.

6. Stones W, Cheong YC, Howard FM, et al. (2015). Interventions for treating chronic pelvic pain in women. Cochrane Database Syst. Rev.

7. Kresch AJ, Seifer DB, Sachs LB, et al. (1984). Laparoscopy in 100 women with chronic pelvic pain. Obstet Gynecol 64(5): 672-674.

8. Krielen P, van den Beukel BA, Stommel MWJ, et al. (2016). In-hospital costs of an admission for adhesive small bowel obstruction. World J Emerg Surg 11: 49.

9. Ivarsson ML, Holmdahl L, Franzén G, et al. (1997).
Cost of bowel obstruction resulting from adhesions. Eur J Surg 163(9): 679-684.

10. Bricker L, Neilson JP and Dowswell T. (2008). Routine ultrasound in late pregnancy (after 24 weeks' gestation). Cochrane Database Syst Rev (4): CD001451.

11. Tittel A, Treutner KH, Titkova S, et al. (2001). New adhesion formation after laparoscopic and conventional adhesiolysis: a comparative study in the rabbit. Surg Endosc; 15:44-46.

12. Barnes D. (2018). Adhesiolysis in Women with Chronic Pelvic Pain and a Temporal Resolution of Pain. Womens Health Sci J, 2(3): 000122.

13. Vrijland WW, Jeekel J, Geldorp HJ, et al. (2003). Abdominal adhesions: intestinal obstruction, pain, and infertility. Surg Endosc; 14:14.

14. El-Minawi AM and Howard FM. (1999). Operative laparoscopic treatment of ovarian retention syndrome. J Am Assoc Gynecol Laparosc 1999;6:297- 302.

15. Swank DJ, Van Erp WF, Repelaer van Driel OJ, et al. (2002) Complications and feasibility of laparoscopic adhesiolysis in patients with chronic abdominal pain. A retrospective study. Surg Endosc 16(10):1468-1473. 
Appendix 1 : GHQ 28

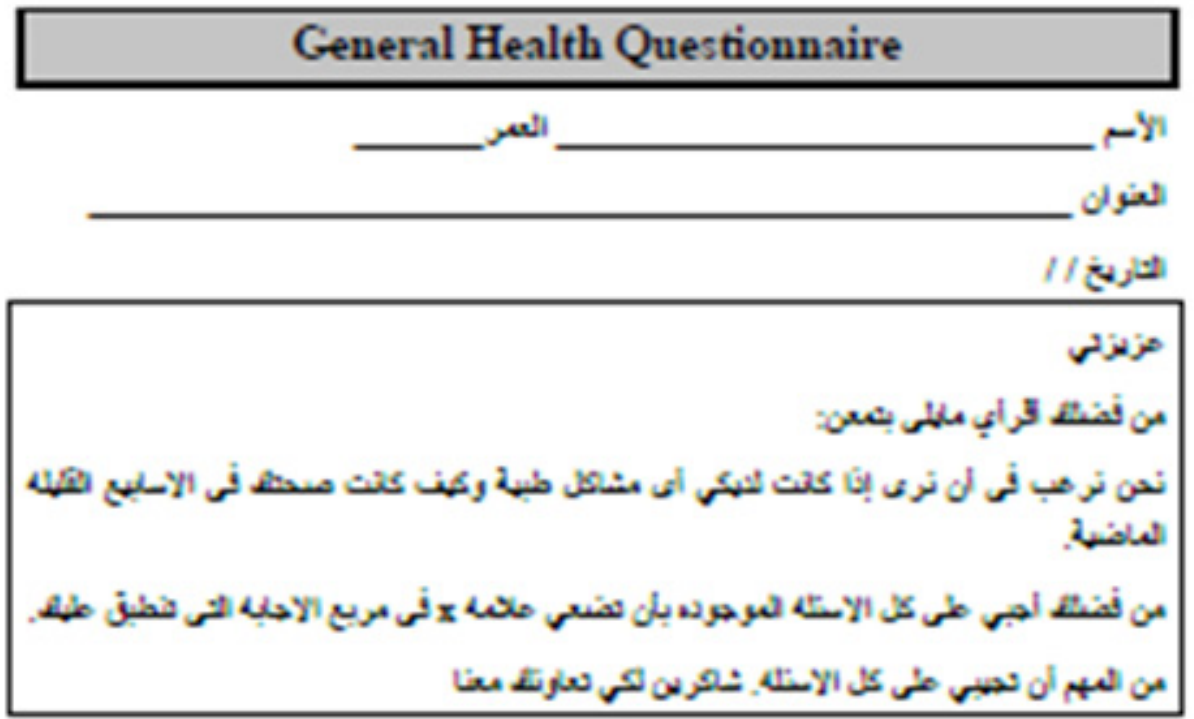

\begin{tabular}{|c|c|c|c|c|c|}
\hline t & 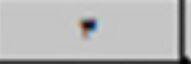 & $*$ & 1 & تصين & \\
\hline 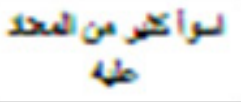 & | & slats & لهol & 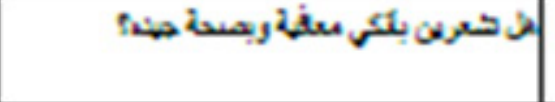 & 1 \\
\hline 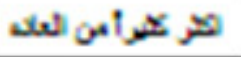 & صر بن لفد & 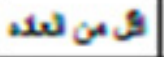 & $y$ & 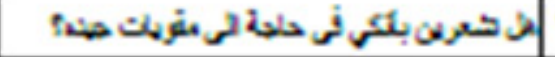 & $\tau$ \\
\hline 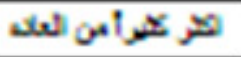 & صر بن فلد & |فلى لف & $y$ & 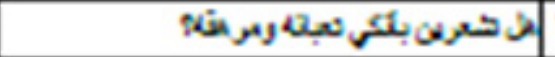 & 7 \\
\hline 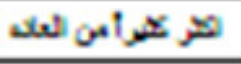 & صز بم لفد & 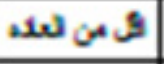 & $y$ & 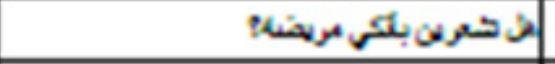 & 6 \\
\hline 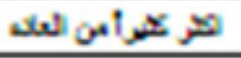 & صر بن فلد & | في لعد & $y$ & 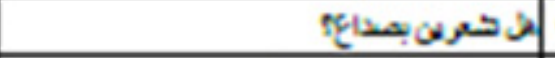 & $\circ$ \\
\hline 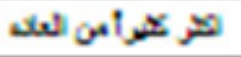 & صر بن سلد & | فل بم الف & $y$ & 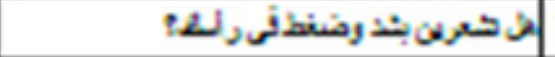 & 1 \\
\hline 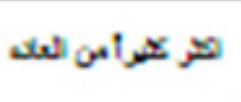 & | صر بم فلد & | ف بم لعد & $y$ & 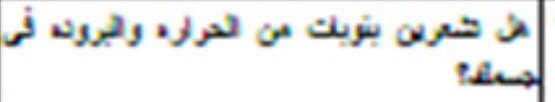 & $\mathrm{v}$ \\
\hline 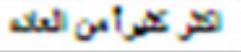 & | صر بم فلى & |ف بر لقد & $\gamma$ & 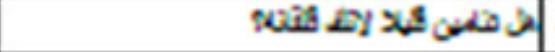 & A. \\
\hline 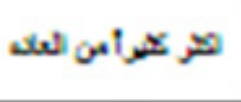 & صز بم لفS & |ف بم لعد & $y$ & 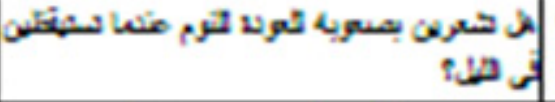 & 4 \\
\hline 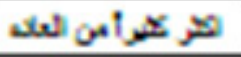 & صر بم سلد & | فل بم لفد & $y$ & 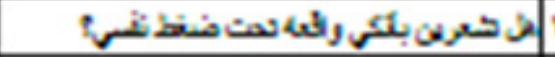 & 1. \\
\hline 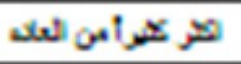 & صز بم سلد & | & $y$ & 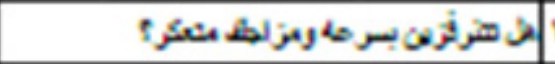 & 11 \\
\hline 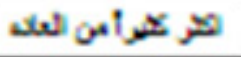 & صر بن فلد & 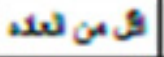 & $y$ & 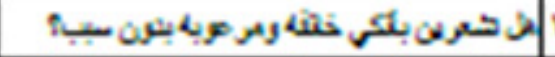 & זיו \\
\hline 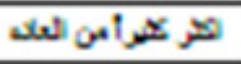 & صز بن لفد & | & $y$ & 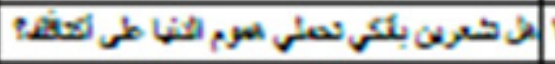 & ir \\
\hline 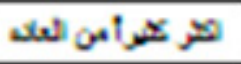 & صز بم فلد & | & $y$ & 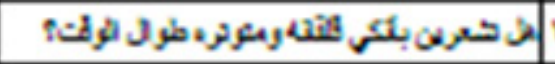 & $1 \mathrm{f}$ \\
\hline
\end{tabular}




\begin{tabular}{|c|c|c|c|c|c|}
\hline c & $\rightarrow$ & 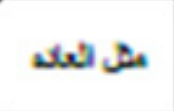 & 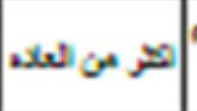 & نا & \\
\hline يم لعلك & 4 & مهل الع & لسرعد & 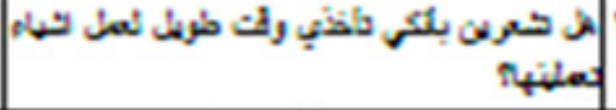 & \\
\hline م لقس & | & ميل أعلد & נa & 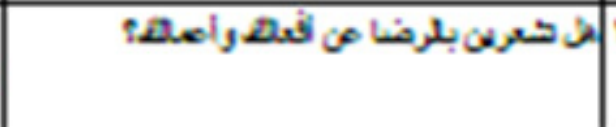 & \\
\hline Uلs & & & | اكتر بن لد & |ل هعريه بكرية & \\
\hline لعلد & & & & 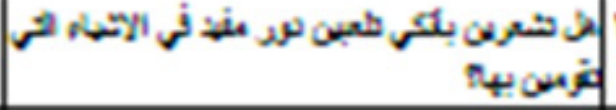 & \\
\hline ملف & ل & & | اكتر بن ال & 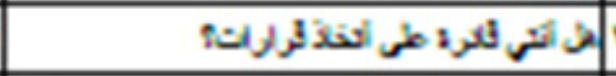 & $\tau$ \\
\hline ( & 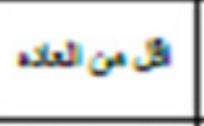 & t. & | اكتر م. & 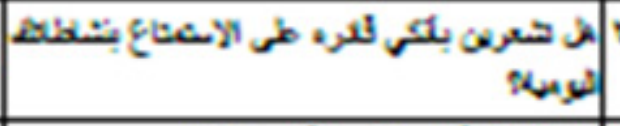 & \\
\hline 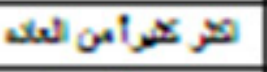 & صر من لفد & في السد & $y$ & 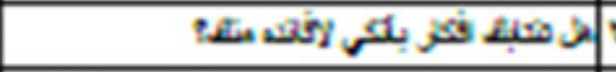 & $\mathrm{rr}$ \\
\hline هير عرأهم العلد & | صر بم فلد & في من لعد & $\gamma$ & 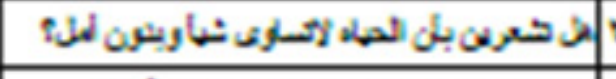 & $\mathrm{rr}$ \\
\hline هر عرأمه العلد & صر من لفد & Listy & 1 & 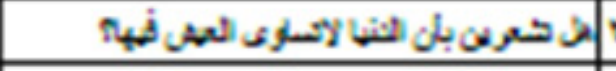 & - \\
\hline نع بالهد & الهت طربل & Lis Iy & y tiber & 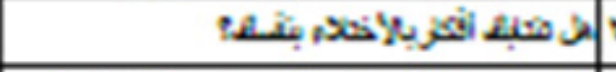 & ro \\
\hline مه العلد & | صر من لفد & فلم لعد & $y$ & 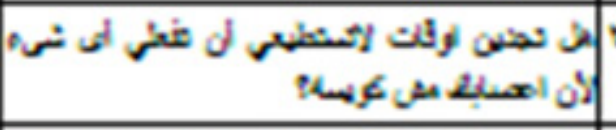 & \\
\hline تصر عيرأهم العلد & |صر بم لعد & فلمن السد & $y$ & 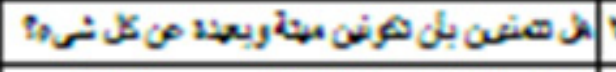 & \\
\hline هر عرأمن العلد & صنر من فلد & Lis ing & ylibs & 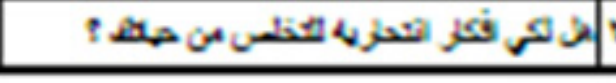 & \\
\hline
\end{tabular}

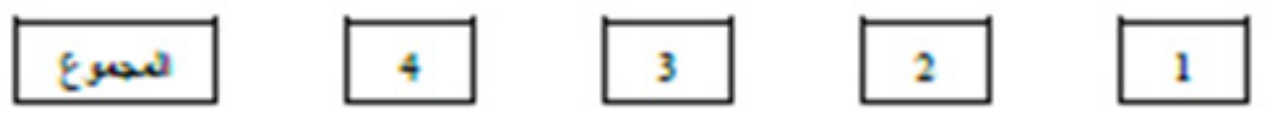

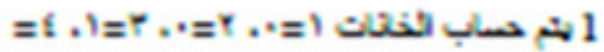

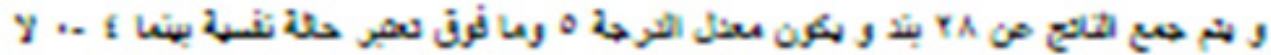

حان

\begin{tabular}{|c|c|c|c|}
\hline תكبي تفدي & 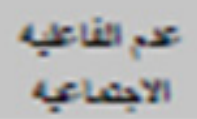 & تصف و الور & تجسيك \\
\hline Yh-tr & 71.10 & If & v-1 \\
\hline
\end{tabular}

